\title{
Analisis Kesulitan Siswa Berdasarkan Kemampuan Pemahaman Matematis dalam Menyelesaikan Soal Cerita Pada Materi SPLDV
}

\author{
Desti Agustini $^{1^{*}}$, Heni Pujiastuti ${ }^{2}$ \\ ${ }^{1,2}$ Pendidikan Matematika FKIP UNTIRTA \\ destiagustini24@gmail.com
}

\begin{abstract}
The purpose of this study was to determine the difficulty of students based on their mathematical understanding ability in solving story problems in the material of the Two Variable Linear Equation System (SPLDV). This type of research uses descriptive research with a qualitative approach. The targets in this study are students of class VIII SMP / MTs as many as 10 people. Data collection was carried out based on mathematical understanding ability test sheets and unstructured interviews. Research subjects are 3 students with the lowest mathematical understanding ability test results. Based on the results of tests and interviews it can be concluded that there are difficulties in students in solving SPLDV questions in the form of stories based on their mathematical understanding abilities. This can be seen from the results of the average score of 57\% which is included in the category of less. As for the difficulties experienced by students that are not yet understanding what is asked in the problem, the difficulty of changing the story problem into a mathematical symbol, students are still unable to interpret terms because it is still difficult to classify objects known in the problem, the difficulty of applying the concept of solving algorithmically with the right method, and the difficulty of linking various concepts in problem solving.
\end{abstract}

Keywords:student difficulties, mathematical understanding abilities, problem stories

Abstrak: Tujuan dari penelitian ini adalah untuk mengetahui kesulitan siswa berdasarkan kemampuan pemahaman matematisnya dalam menyelesaikan soal cerita pada materi Sistem Persamaan Linear Dua Variabel(SPLDV). Jenis penelitian ini menggunakan penelitian deskriptif dengan pendekatan kualitatif. Sasaran dalam penelitian ini yaitu siswa kelas VIII SMP/MTs sederajat sebanyak 10 orang. Pengumpulan data dilakukan berdasarkan lembar tes kemampuan pemahaman matematis dan wawancara tidak terstruktur. Subjek penelitian yaitu 3 orang siswa dengan hasil tes kemampuan pemahaman matematis terendah. Berdasarkan hasil tes dan wawancara dapat disimpulkan bahwa terdapat kesulitan pada siswa dalam menyelesaikan soal SPLDV dalam bentuk cerita berdasarkan pada kemampuan pemahaman matematisnya. Hal ini dapat kita lihat dari hasil skor rata-rata nya yaitu sebesar 57\% yang termasuk ke dalam kategori kurang. Adapun kesulitan-kesulitan yang di alami siswa yaitu belum memahami apa yang ditanyakan dalam soal, kesulitan mengubah soal cerita ke dalam simbol matematika, siswa masih kurang mampu memisalkan istilah karena masih kesulitan dalam mengklasifikasikan objek yang diketahui dalam soal, kesulitan menerapkan konsep penyelesaian secara algoritma dengan metode yang tepat, dan kesulitan mengaitkan berbagai konsep dalam penyelesaian soal.

Kata kunci: kesulitan siswa, kemampuan pemahaman matematis, soal cerita

\section{PENDAHULUAN}

Pendidikan merupakan salah satu hal penting yang dibutuhkan oleh setiap orang, karena dengan pendidikan seseorang dapat memiliki pengetahuan serta keterampilan yang berguna sekali dalam proses kehidupan. Matematika merupakan sebuah ilmu pasti yang menjadi dasar bagi ilmu pengetahuan lain, oleh karenanya matematika saling berkaitan dengan ilmu pengetahuan lain. Matematika juga menjadi salah satu mata pelajaran wajib yang selalu ada pada setiap jenjang pendidikan khususnya di Indonesia.Matematika termasuk kedalam salah satu mata pelajaran yang dalam proses pembelajarannya tidak hanya dengan hafalan rumus saja, namun membutuhkan tingkat pemahaman yang tinggi(Sholekah et al., 2017).Pemahaman dalam pembelajaran adalah 
tingkat kemampuan yang mengharapkan seseorang mampu memahami arti atau konsep, situasi serta fakta yang diketahuinya (Moreno, 2018). Menurut Syarifah (2017) kemampuan pemahaman matematis merupakan suatu kekuatan yang harus diperhatikan dan diperlakukan secara fungsional dalam proses dan tujuanpembelajaran matematika, terlebih lagi sense memperoleh pemahaman matematis pada saat pembelajaran, hal tersebut hanya bisa dilakukan melalui pembelajaran dengan pemahaman.

Matematika dicapsebagai mata pelajaran yang sulit dan juga membosankan, maka dari itu banyak siswa yang malas untuk belajar matematika. Hal ini karena banyak siswa mengalami kesulitan untuk mempelajari matematika yang objek kajiannya bersifat abstrak (Farida, 2015). Kesulitan belajar merupakan kondisi dimana siswa mengalami hambatan dalam proses pembelajaran, salah satunya yaitu siswa tidak memahami materi yang diajarkan.Kesulitan siswa dalam mempelajari matematika dikarenakan siswa tidak membangun sendiri tentang pengetahuan konsep-konsep matematika melainkan cenderung menghafalkan konsep-konsep matematika tanpa mengetahui makna yang terkandung pada konsep tersebut sehingga saat siswa menyelesaikan masalah matematika siswa sering melakukan kesalahan dan tidak menemukan solusi penyelesaian masalahnya(Hardiyanti, 2016).Kondisi ini tentu saja berpengaruh terhadap hasil belajar siswa, sehingga tingkat keberhasilan pembelajaran matematika menjadi rendah.Matematika berhubungan dengan simbol, grafik, dan angka- angka, sehingga menyebabkan siswa tidak suka dengan pelajaran matematika khususnya dalam menyelesaikan soal cerita (Rahmawati, 2019).

Soal cerita matematika merupakan salah satu bentuk soal matematika yang memuat aspek kemampuan untuk membaca, menalar, menganalisis serta mencari solusi, untuk itu siswa dituntut dapat menguasai kemampuan-kemampuan dalam menyelesaikan soal cerita matematika tersebut (Khasanah \& Sutaman, 2015). Soal bentuk cerita pada materi matematika membutuhkan pemahaman yang lebih jika dibandingkan dengan soal lain, dalam menyelesaikan soal cerita matematika bukan hal yang mudah karena dalam penyelesaiannya tidak hanya bergantung pada jawaban akhir saja, namun juga dilihat pada proses penyelesainnya (Nugroho \& Sutarni, 2017). Namun, saat ini masih banyak sekali siswa yang mengalami kesulitan dalam menyelesaikan soal bentuk cerita, menurut Widyaningrum(2016) untuk dapat menyelesaikan soal cerita dengan benar diperlukan kemampuan awal, yaitu 1) kemampuan membaca soal, 2) kemampuan menentukan apa yang diketahui dan apa yang ditanyakan dalam soal, 3) kemampuan membuat model matematika, 4) kemampuan melakukan perhitungan, dan 5) kemampuan menulis jawaban akhir dengan tepat. Dalam menyelesaikan sebuah soal cerita, siswa harus memahami terlebih dulu materi apa yang telah ia pelajari. Pemahaman akan membantu siswa mengembangkan bagaimana berpikir dan bagaimana membuat keputusan (Sariningsih, 2014). Oleh karena itu, kemampuan pemahaman matematis merupakan kemampuan yang perlu dikuasai oleh siswa khususnya dalam menyelesaikan soal cerita.

Fitriani \& Maulana(2016) dalam artikelnya menyimpulkan bahwa, kemampuan pemahaman matematis adalah kemampuan seseorang dalam mengingat, memahami, 
menjelaskan, dan menerapkan konsep matematika untuk menyelesaikan masalah dalam kehidupan sehari-hari.Sedangkan menurut Purwasih(2015)Pemahaman konsep matematis merupakan dua aspek kemampuan yang perlu dikembangkan pada saat pembelajaran matematika agar siswa mampu memahami dan memecahkan masalah matematika yang sedang dihadapinya. Pentingnya kemampuan pemahaman matematis pada siswa menjadi salah satu acuan untuk guru dalam mengembangkan sebuah pembelajaran di kelas agar siswa terlibat aktif dalam pembelajaran matematika, tidak hanya menghapal rumus namun siswa juga mampu memahami konsep dari materi yang sedang ia pelajari. Seseorang yang memiliki kemampuan pemahaman matematis berarti orang tersebut sudah mengetahui apa yang sedang dipelajarinya, langkah-langkah yang telah dilakukan, dan dapat menggunakan konsep matematika baik didalam ataupun diluar konteks matematika(Alan \& Afriansyah, 2017).

Sistem Persamaan Linear Dua Variabel (SPLDV) termasuk salah satu materi wajib yang perlu dikuasai oleh peserta didik dalam pembelajaran matematika, karena materi SPLDV ini berkaitan dengan materi yang akan dipelajari selanjutnya. Berdasarkan wawancara dengan Ibu Suwarningsih, S.Pd selaku guru mata pelajaran matematika, hasil ulangan pada materi sistem persamaan linear dua variabel menunjukan bahwa 55,9\% siswa belum mencapai kriteria ketuntasan minimal <70(Puspitasari et al., 2015). Selain itu, dalam materi SPLDV ini kebanyakan soal yang muncul ialah soal dalam bentuk cerita.Menurut Resta \& Munawaroh (2018)tingkat kesalahan yang dilakukan siswa dalam menyelesaikan soal matematika dalam bentuk cerita masih tergolong tinggi pada materi sistem persamaan linear dua variabel. Halini menunjukkan bahwa kemampuan pemahaman matematis siswa khususnya dalam menyelesaikan soal cerita pada materi SPLDV masih rendah sehingga siswa mengalami kesulitan dalam menyelesaikan soal.Maka dari itu peneliti memilih materi SPLDV dalam penelitian ini.Penelitian ini bertujuan untuk mengetahui kesulitansiswa berdasarkan kemampuan pemahaman matematisnyadalam menyelesaikan soal cerita pada materi SPLDV.

\section{METODE}

Metode yang digunakan dalam penelitian ini menggunakan jenis penelitian deskriptif dengan pendekatan kualitatif.Menurut Sukmadinata (2011) yang dikutip oleh (Kurniawan et al., 2019)menyatakan bahwa penelitian deskriptif kualitatif ditujukan untuk mendeskripsikan dan menggambarkan fenomena-fenomena yang ada, baik bersifat alamiah maupun rekayasa manusia,yang lebih memperhatikan mengenai karakteristik, kualitas, dan keterkaitan antar kegiatan. Penelitian inidilakukan untuk mendeskripsikan kesulitansiswa berdasarkan kemampuan pemahamanmatematisnya dalam menyelesaikan soal cerita pada materi SPLDV. Sasaran penelitian yaitu siswa kelas VIII SMP/MTs sederajat sebanyak 10 orang. Subjek penelitiandiambil 3 orang siswa yang mendapatkan skor terendah pada hasil tes kemampuan pemahaman matematis berbentuk soal cerita pada materi SPLDV. 
Instrumen penelitian menggunakan tes kemampuan pemahaman matematis dengan tes tertulis dalam bentuk uraian/essay dan wawancara tidak terstruktur. Indikator kemampuan pemahaman matematis yang digunakan pada penelitian ini yaitu,kemampuan menyatakan ulang konsep yang telah dipelajari. Kemampuan mengklasifikasi objek-objek berdasarkan dipenuhi atau tidaknya persyaratan yang membentuk konsep tersebut, kemampuan menerapkan konsep secara algoritma, dan kemampuan mengaitkan berbagai konsep.Teknik analisis datayaitu dengan menilai jawaban dari tes yang telah dilakukan,menggunakan rumus:

$$
S=\frac{\text { skor yang diperoleh siswa }}{\text { skor maksimal }} \times 100 \%
$$

Adapun skor kemampuan pemahaman siswa mengacu pada pendapat (Huda \& Kencana, 2013), dapat dilihat pada tabel 1 berikut ini.

Tabel 1. Skor Kemampuan Pemahaman Siswa

\begin{tabular}{cc}
\hline Skor(dalam persen) & Kategori \\
\hline $86-100$ & Sangat Baik \\
$76-85$ & Baik \\
$60-75$ & Cukup \\
$55-59$ & Kurang \\
Kurang dari 54 & Sangat Kurang \\
\hline
\end{tabular}

Secara umum prosedur dalam penelitian ini terdiri dari tahap perencanaan penelitian, penyusunan instrumen penelitian, pelaksanaan penelitian, analisis data dan penarikan kesimpulan. Berikut prosedur atau alur penelitian yangtergambarkan dalam Gambar 1.

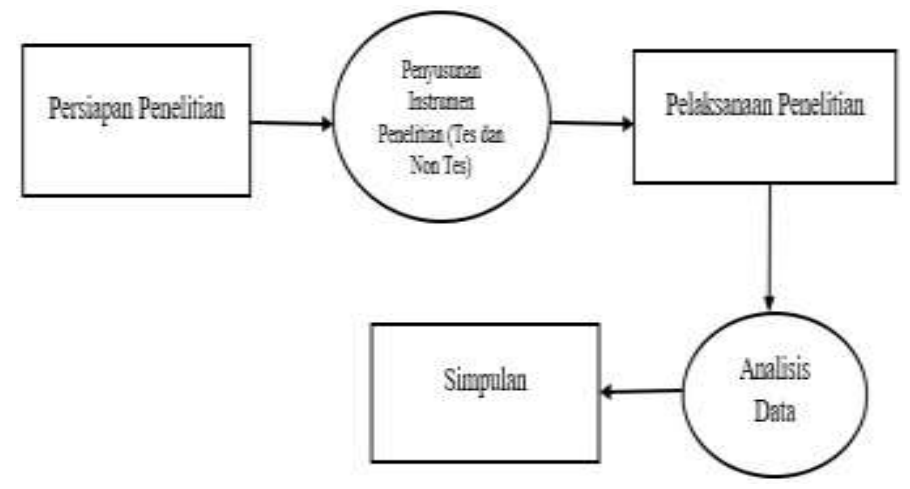

Gambar 1. Prosedur Penelitian

\section{HASIL DAN PEMBAHASAN}

Data pada penelitian ini berupa hasil tes tertulis dalam bentuk uraian/essay sebanyak 4 soal dalam bentuk cerita yang mengacu pada indikator kemampuan pemahaman matematis. Selain itu, dilakukan wawancara kepada 3 orang siswa yang mendapatkan hasil tes kemampuan pemahaman matematis terendah. Berikut ini tabel 
hasil tes kemampuan pemahaman matematis yang telah dilakukan oleh siswa kelas VIII sebanyak 10 orang.

Tabel2. Hasil Tes Kemampuan Pemahaman Matematis Siswa

\begin{tabular}{cccc}
\hline No & Subjek Penelitian & Skor(dalam persen) & Kategori \\
\hline 1 & SK1 & 83 & Baik \\
2 & SK2 & 75 & Cukup \\
3 & SK3 & 67 & Kurang \\
4 & SK4 & 58 & Kurang \\
5 & SK5 & 58 & Kurang \\
6 & SK6 & 58 & Kurang \\
7 & SK7 & 50 & Sangat Kurang \\
8 & SK8 & 50 & Sangat Kurang \\
9 & SK9 & 42 & Sangat Kurang \\
10 & SK10 & 33 & Sangat Kurang \\
& Jumlah rata-rata & $\mathbf{5 7}$ & Kurang \\
\hline
\end{tabular}

Berdasarkan tabel 2, terdapat 1 orang siswa yang mendapatkan skor dengan kategori baik, 1 orang siswa dengan kategori cukup, 4 orang siswa dengan kategori kurang dan 4 orang siswa dengan kategori sangat kurang. Hasil tes kemampuan pemahaman matematis berbentuk soal cerita pada materi SPLDV seperti terlihat pada tabel menunjukkan skor rata-rata 57\%, sehingga termasuk kedalam kategori kurang.

Tahap selanjutnya yaitu wawancara tidak terstruktur, yang dipilih sebagai subjek penelitian untuk dilakukan analisis kesulitannya yaitu SK8(Siswa Ke-8), SK9(Siswa Ke-9) dan SK10(Siswa Ke-10). Adapun sebaran tes yang dilakukan siswa dapat diuraikan sebagai berikut:

1) Kemampuan menyatakan ulang konsep yang telah dipelajari.

Soal nomor 1: Harga 3 buku tulis dan pensil adalah Rp13.000,00, sedangkan harga 5 buku tulis dan pensil adalah Rp15.000,00. Dapatkah kamu menghitung harga satuan untuk buku tulis dan pensil tersebut?Permasalahan-permasalahan aritmetika sosial seperti ini dapat diselesaikan dengan mudah menggunakan Sistem Persamaan Linier Dua Variabel (SPLDV).Jadi, apakah yang dimaksud dengan Sistem Persamaan Linear Dua Variabel? Jelaskan!

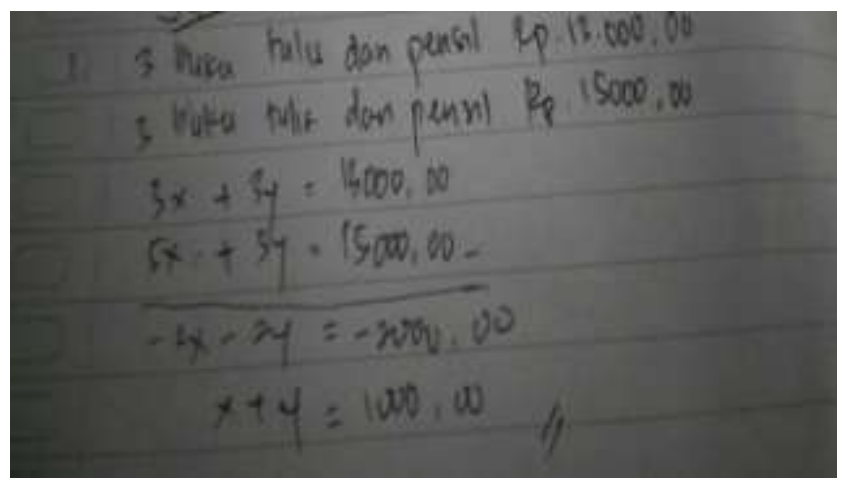

Gambar 2. Jawaban Subjek SK8 
Berdasarkan gambar di atas, jawaban dari subjek SK8 menunjukkan bahwa subjek belum memahami apa yang ditanyakan dalam soal cerita tersebut. Dalam soal tersebut yang ditanyakan adalah pengertian atau konsep dari SPLDV. Setelah di wawancara ternyata subjek hanya membaca soal tanpa memahami maksudnya, sehinga subjek tidak dapat menjawab soal dengan benar. Hal ini menunjukkan bahwa subjek mengalami kesulitan dalam mengubah soal bentuk cerita ke dalam kalimat matematika, yang disebabkan karena kurangnya membaca untuk memahami apa yang di tanyakan dalam soal,sehingga subjek tidak dapat menyatakan konsep atau pengertian dari SPLDV.

2) Kemampuanmengklasifikasi objek-objek berdasarkan dipenuhi atau tidaknya persyaratan yang membentuk konsep tersebut

Soal nomor 2: Susi membeli $1 \mathrm{~kg}$ daging sapi dan $2 \mathrm{~kg}$ ayam potong dengan harga Rp94.000,00. Nova membeli $3 \mathrm{~kg}$ ayam potong dan $2 \mathrm{~kg}$ daging sapi dengan harga Rp167.000,00. Harga $1 \mathrm{~kg}$ daging sapi dinyatakan dengan x dan $1 \mathrm{~kg}$ ayam dinyatakan dengan y. Tentukanlah model SPLDV dari pernyataan tersebut!

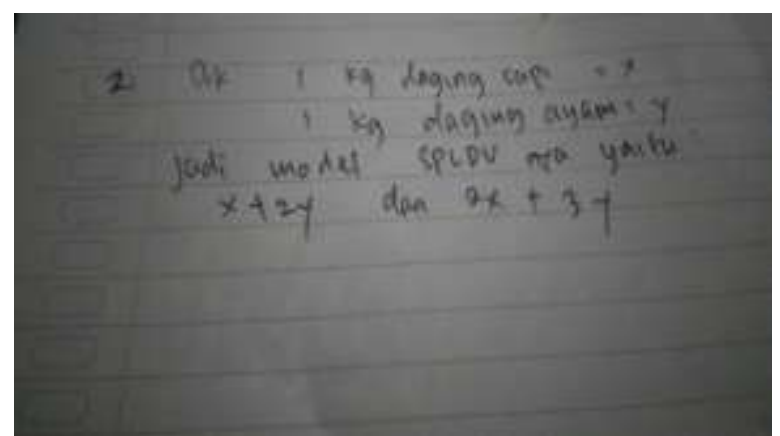

Gambar 3. Jawaban SubjekSK8

Berdasarkan gambar di atas, jawaban dari subjek SK8 masih belum lengkap. Subjek tidak mencantumkan apa yang ditanya dan dalam menuliskan model matematika nya kurang lengkap karena tidak mencantumkan harga dari setiap pembelian. Setelah dilakukan wawancara ternyata subjek mengalami kesulitan dalam memisalkan istilah yang akan dibuat kedalam bentuk variabel. Ini menunjukkan bahwa subjek masih belum mampu mengklasifikasikan objek yang diketahui.

3) Kemampuan menerapkan konsep secara algoritma

Soal nomor 3: Di dalam kandang terdapat kambing dan ayam sebanyak 13 ekor. Jika jumlah kaki hewan tersebut 32 ekor, maka jumlah kambing dan ayam masingmasing adalah.... 


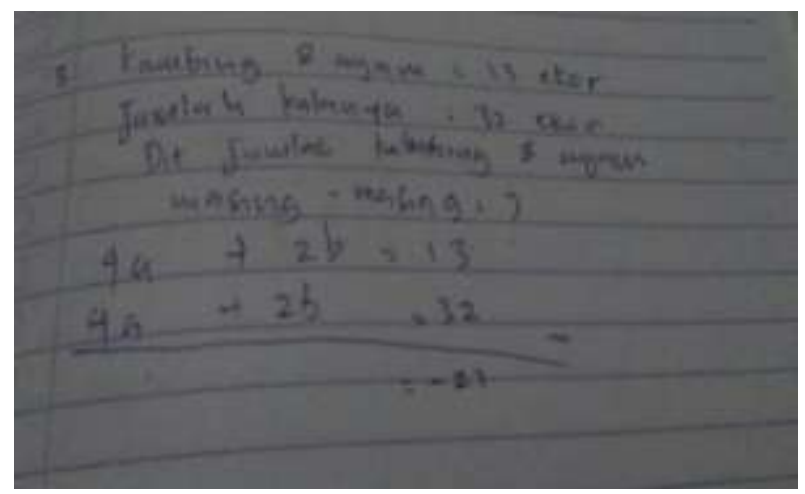

Gambar 4. Jawaban Subjek SK9

Berdasarkan gambar di atas, jawaban dari subjek SK9 menunjukkan bahwa subjek tidak dapat menyelesaikan soal tersebut. Subjek hanya mengerjakan sampai membuat model matematikanya saja, itupun masih kurang tepat. Setelah dilakukan wawancara ternyata subjek mengalami kesulitan dalam melakukan operasi aljabar dengan metode eliminasi dan substitusi. Hal ini menunjukkan bahwa subjek belum mampu menerapkan konsep penyelesaian SPLDV secara algoritma.

4) Kemampuan mengaitkan berbagai konsep

Soal nomor 4: Harga 4 buah donat dan 5 buah roti kukus adalah Rp 4.550,00. Sedangkan harga 2 buah donat dan 3 buah roti kukus adalah Rp 2.550,00. Tentukan harga 1 buah donat dan 2 buah roti kukus!

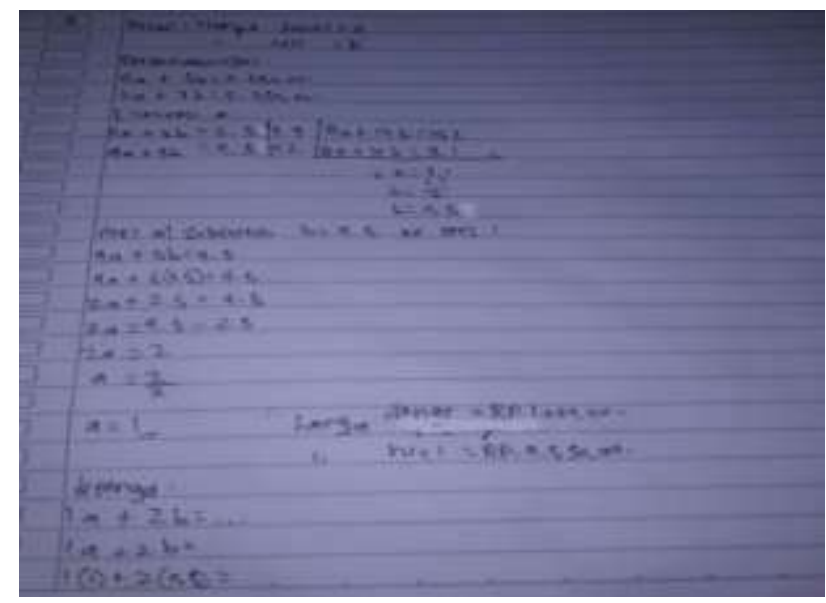

Gambar 5. Jawaban SubjekSK10

Berdasakan gambar di atas, jawaban dari subjek SK10 menunjukkan bahwa subjek belum dapat menyelesaikan soal dengan jawaban yang benar. Terlihat bahwa subjek masih kurang tepat dalam melakukan operasi aljabar dengan metode eliminasi, karena hasil dari eliminasi salah menyebabkan hasil metode substitusi juga salah. Selain itu, dalam penyelesaian hasil akhir dan penulisan kesimpulan pun belum tepat. Ini sangat berpengaruh terhadap hasil akhir karena antar konsep saling terkait. Setelah di wawancara ternyata subjek masih mengalami kesulitan karena tidak menguasai konsep 
dari penyelesaian operasi penjumlahan dan pengurangan, selain itu subjek juga kurang menguasai keterampillan berhitung.

Berdasarkan tabel 2, dapat dilihat bahwa kemampuan pemahaman matematis siswa dalam menyelesaikan soal cerita pada materi SPLDV masih dikategorikan ke dalam kategori kurang. Hal ini terjadi karena siswa mengalami kesulitan dalam proses penyelesaiannya. Hasil wawancara terhadap subjek dengan hasil tes kemampuan terendah menunjukkan bahwa siswa belum memahami apa yang ditanyakan dalam soal, sehingga siswa melakukan kesalahan dalam menyatakan ulang sebuah konsep. Hal ini sejalan dengan penelitian Ananda (2018) Kesalahan konsep dilakukan sebanyak 33,33\% dari jawaban keseluruhan, kesalahan ini dilakukan karena siswa belum memahami dengan baik apa yang ditanyakan dalam soal sehingga pada saat menyelesaikan soal siswa cenderung salah menafsirkan apa yang diminta oleh soal. Hal tersebut disebabkan karena kebiasaan malas siswa dalam membaca, khususnya dalam membaca soal cerita. Siswa juga kurang teliti dalam membaca soal sehingga tidak memahami apa yang ditanyakan. Senada dengan Kurniawan (2019) yang mengungkapkan bahwa sebagian besar siswa masih kurang mampu menuliskan apa yang diketahui dan apa yang ditanyakan dari soal sebelum menjawab soal.

Selain itu, kesulitan yang di alami siswa yaitu dalam mengubah soal cerita ke dalam simbol matematika, siswa masih kurang mampu memisalkan istilah karena masih kesulitan dalam mengklasifikasikan objek yang diketahui dalam soal. Kemudian siswa juga mengalami kesulitan dalam menerapkan konsep penyelesaian secara algoritma, hal ini ditandai dengan adanya kesalahan siswa dalam menyelesaikan operasi aljabar dengan metode eliminasi, subjek juga kurang menguasai keterampillan berhitung yang merupakan salah satu materi prasyarat. Sejalan dengan hasil penelitian (Hikmah et al., 2019) yang mengatakan siswa berkemampuan rendah mengalami kesulitan dari aspek pengetahuan prasyarat atau pemahaman tentang materi sebelumnya. Akibatnya, siswa juga melakukan kesalahan dalam menyelesaikan operasi aljabar pada metode substitusi dan jawaban pada hasil akhir. Hal ini dikarenakan antar konsep saling berkaitan, sehingga jika proses penyelesaian yang dilakukan di awal sudah salah maka hasil akhir dan kesimpulan nya pun akan salah. Hal tersebut sejalan dengan hasil penelitian Rahmawati (2019) bahwa kesulitan yang dialami siswa yaitu dalam penulisan simbol matematika, tidak menuliskan diketahui dan ditanya dengan tepat, tidak menggunakan metode dengan tepat, kesalahan dalam menentukan hasil akhir dan menuliskan kesimpulan.

\section{SIMPULAN DAN SARAN}

Berdasarkan hasil penelitian yang telah dilakukan, dapat disimpulkan bahwa terdapat kesulitan pada siswa dalam menyelesaikan soal SPLDV dalam bentuk cerita berdasarkan pada kemampuan pemahaman matematisnya. Hal ini dapat kita lihat dari hasil skor rata-ratanya yaitu sebesar 57\% yang termasuk kedalam kategori kurang. Adapun macam-macam kesulitan yang dialami siswa yaitu:

1) Belum memahami apa yang di tanyakan dalam soal. 
2) Mengubah soal cerita ke dalam simbol matematika, siswa masih kurang mampu memisalkan istilah karena masih kesulitan dalam mengklasifikasikan objek yang diketahui dalam soal

3) Menerapkan konsep penyelesaian secara algoritma dengan metode yang tepat.

4) Mengaitkan berbagai konsep dalam penyelesaikan soal.

Saran bagi pendidik atau guru hendaknya mencari tahu letak kesulitan-kesulitan yang dialami siswanya, sehingga mampu meminimalisir kesulitan-kesulitan tersebut dengan memberikan bimbingan serta arahan. Bagi peneliti lain yang ingin melnjutkan penelitian ini, dapat mencari materi yang berbeda atau lebih di gali lagi letak kesulitankesulitan yang di alami oleh siswa, diharapkan penelitian ini dapat dijadikan sumber referensi bagi peneliti lain.

\section{DAFTAR PUSTAKA}

Alan, U. F., \& Afriansyah, E. A. (2017). Kemampuan Pemahaman Matematis Siswa Melalui Model Pembelajaran Auditory Intellectualy Repetition Dan Problem Based Learning. Jurnal Pendidikan Matematika, 11(1). https://doi.org/10.22342/jpm.11.1.3890.67-78

Ananda, R. P., Sanapiah, S., \& Yulianti, S. (2018). Analisis Kesalahan Siswa Kelas Vii Smpn 7 Mataram Dalam Menyelesaikan Soal Garis Dan Sudut Tahun Pelajaran 2018/2019. Media Pendidikan Matematika, 6(2), 79. https://doi.org/10.33394/mpm.v6i2.1838

Farida, N. (2015). Analisis Kesalahan Siswa SMP Kelas VIII dalam Menyelesaikan Masalah Soal Cerita Matematika. Aksioma, 151(2005), 10-17. https://doi.org/10.1145/3132847.3132886

Fitriani, K., \& Maulana. (2016). Meningkatkan Kemampuan Pemahaman Dan Pemecahan Masalah Matematis Siswa SD Kelas V Melalui Pendekatan Matematika Realistik. Mimbar Sekolah Dasar, 3(1), 40-52. https://doi.org/10.17509/mimbar-sd.v3i1.2355

Hardiyanti, A. (2016). Analisis Kesulitan siswa dalam menyelesaikan soal matematika pada materi barisan dan deret. Konferensi Nasional Penelitian Matematika Dan Pembelajarannya (KNPMP I), 2(2), 78-88.

Hikmah, A., Roza, Y., \& Maimunah, M. (2019). Analisis Kemampuan Komunikasi Matematis Siswa Smp Pada Soal Spldv. Media Pendidikan Matematika, 7(1), 29. https://doi.org/10.33394/mpm.v7i1.1428

Huda, N., \& Kencana, A. G. (2013). Analisis kesulitan siswa berdasarkan kemampuan pemahaman dalam menyelesaikan soal cerita pada materi kubus dan balok di kelas VIII SMP Negeri 30 Muaro Jambi. Prosiding Semirata FMIPA Lampung, 1, 595606.

Khasanah, U., \& Sutaman. (2015). Kesulitan Menyelesaikan Soal Cerita Matematika pada Siswa SMP. Publikasi Ilmiah, 1-13. 
Kurniawan, A., Juliangkary, E., \& Pratama, M. Y. (2019). Analisis Kesulitan Siswa Dalam Menyelesaikan Soal Fungsi. Media Pendidikan Matematika, 7(1), 72. https://doi.org/10.33394/mpm.v7i1.1679

Moreno, L. (2018). Penerapan Metode Discovery Learning untuk Meningkatkan Kemampuan Pemahaman Matematis Siswa Kelas VII SMPN 25 Pekanbaru. Jurnal Pendidikan Tambusai, 2(6), 1401-1428.

Nugroho, R. A., \& Sutarni, S. (2017). Analisis Kesulitan Siswa Dalam Menyelesaikan Soal Cerita Pada Materi Pecahan Ditinjau Dari Pemecahan Masalah Polya. Electronic Thesis and Dissertations Universitas Muhammadiyah Surakarta.

Purwasih, R. (2015). Peningkatan Kemampuan Pemahaman Matematis Dan Self Confidence Siswa MTs Di Kota Cimahi Melalui Model Pembelajaran Inkuiri Terbimbing. Jurusan Pendidikan Matematika, STKIP Siliwangi Bandung, 9(1), $16-25$.

Puspitasari, E., Yusmin, E., \& Nursangaji, A. (2015). Analisis Kesulitan Siswa Menyelesaikan Soal Cerita Materi Sistem Persamaan Linear Dua Variabel Di SMP. Jurnal Pendidikan Dan Pembelajaran Untan, 1-9.

Rahmawati, A. (2019). Analisis Kesulitan Siswa dalam Menyelesaikan Soal Cerita Matematika Berbasis Pembelajaran Pemecahan Masalah Kelas V SD Negeri Gebangsari 03. Jurnal Pengembangan Pembelajaran Matematika, I(2), 30-37.

Resta, E. L., \& Munawaroh. (2018). KEMAMPUAN PEMAHAAN MATEMATIS SISWA PADA MATERI SEGIEMPAT. Jurnal Pendidikan Tambusai, 2(1), 17101718.

Sariningsih, R. (2014). Pendekatan Kontekstual Untuk Meningkatkan Kemampuan Pemahaman Matematis Siswa SMP. Infinity Journal, 3(2), 151. https://doi.org/10.22460/infinity.v3i2.p150-163

Sholekah, L. M., Anggreini, D., \& Waluyo, A. (2017). Analisis Kesulitan Siswa dalam Menyelesaikan Soal Matematika Ditinjau Dari Koneksi Matematis Materi Limit Fungsi. WACANA AKADEMIKA: Majalah Ilmiah Kependidikan, 1(2), 151-164. https://doi.org/10.30738/wa.v1i2.1413

Syarifah, L. L. (2017). Analisis Kemampuan Pemahaman Matematis Pada Mata Kuliah Pembelajaran Matematika SMA II. Jurnal Penelitian Dan Pembelajaran Matematika, 10(2), 57-71. https://doi.org/10.30870/jppm.v10i2.2031

Widyaningrum, A. Z. (2016). Analisis Kesulitan Siswa Dalam Mengerjakansoal Cerita Matematika Materi Aritmatika Sosial Ditinjau Dari Gaya Belajar Siswa Kelas VII SMP Negeri 5 Metro Tahun Pelajaran 2015/2016. IOSR Journal of Economics and Finance, 3(1), 56. https://doi.org/10.3929/000238666 